well nourished neonates does not affect the specific activity of synaptosomal $\mathrm{Na}^{+}-\mathrm{K}^{+}$-ATPase from the cerebellum but does appear to inhibit the development of cerebral ATPase. Body weight gain in these animals is greatly decreased.

\section{REFERENCES AND NOTES}

1. Abdel-Latif, A. A., Smith, J. P., and Ellington, E. P.: Subcellular distribution of sodium-potassium adenosine triphosphatase, acetylcholine and acetylcholinesterase in developing rat brain. Brain Res., 18: 441 (1970).

2. Abdel-Latif, A. A., Smith, J. P., and Hedrick, N.: Adenosine triphosphate and nucleotide metabolism in synaptosomes of rat brain. J. Neurochem., 17: 391 (1970).

3. Adlard, B. P. F., DeSouza, S. W., and Dobbing, J.: Effects of growth retardation and asphyxia on brain electrolytes and on glycolysis in developing rats. Pediat. Res., 7: 494 (1973).

4. Adlard, B. P. F., and Dobbing, J.: Vulnerability of developing brain. V. Effects of fetal and postnatal undernutrition on regional brain enzyme activities in three-week-old rats. Pediat. Res., 6: 38 (1972).

5. Bass, N. H., Netsky, M. G., and Young, E.: Effect of neonatal malnutrition on developing cerebrum. I. Microchemical and histologic study of cellular differentiation in the rat. Arch. Neurol., 23: 289 (1970).

6. Fish, I., and Winick, M.: Cellular growth in various regions of the developing rat brain. Pediat. Res., 3: 407 (1969).

7. Fiske, C. H., and SubbaRow, Y.: Colorimetric determination of phosphorous. J. Biol. Chem., 66: 375 (1925).

8. Globus, A., Rosenzweig, M. R., and Bennett, E. L., et al.: Effects of differential experience on dendritic spine counts in rat cerebral cortex. J. Comp. Physiol. Psychol., 82: 175 (1973).

9. Hawrylewicz, E. J., and Kissane, J. Q.: Studies on neonatal brain adenine nucleotide levels as a function of protein restricted diets

Copyright $\odot 1975$ International Pediatric Research Foundation, Inc. and age. Report to the American Society for Neurochemistry, Columbus, Ohio, March 13, 1973.

10. Hawrylewicz, E. J., and Kissane, J. Q., and Heppner, C. A.: Effect of maternal protein malnutrition on perinatal brain mitochondria function. Nutr. Rep. Int., 4: 279 (1971).

11. Kissane, J. Q., and Hawrylewicz, E. J. Effect of maternal protein malnutrition upon the development of synaptosomal $\mathrm{Na}^{+}-\mathrm{K}^{+}$. ATPase activity in neonatal rats. Fed. Proc., 32: 902 (1973).

12. Lowry, O. H., Rosebrough, N. J., Farr, H. L., and Randall, R. J.: Protein measurement with the Folin phenol reagent. J. Biol. Chem., 193: 265 (1951).

13. Ozawa, K., Seta, K., Takeda, H., et al.: On the isolation of mitochondria with high respiratory control from rat brain. J. Biochem. (Tokyo), 59: 501 (1966).

14. Samson, F. E., and Quinn, D. J.: $\mathrm{Na}^{+}-\mathrm{K}^{+}$-activated ATPase in rat brain development. J. Neurochem., 14: 421 (1967).

15. Verity, M. A.: Cation modulation of synaptosomal respiration. J. Neurochem., 19:1305 (1972).

16. Winick, M.: Malnutrition and brain development. J. Pediat Res., 74: 667 (1969).

17. Winick, J.: Cellular growth during early malnutrition. Pediatrics, 47: 969 (1971).

18. Zamenhof, S., van Marthens, E., and Margolis, F. E.: DNA (cell number) and protein in neonatal brain: Alteration by maternal dietary protein restriction. Science, 160: 3825 (1968).

19. Nutritional Biochemical Co., Cleveland, Ohio.

20. Cabiochem, LaJolla, Calif.

21. Sigma Chemical Co., St. Louis, Mo.

22. This research was supported by The John A. Hartford Foundation, Inc., New York.

23. Requests for reprints should be addressed to: E. J. Hawrylewicz, Ph.D., Department of Research, Mercy Hospital and Medical Center, Stevenson Expressway at King Dr., Chicago, Ill. 60616 (USA).

24. Accepted for publication November $25,1974$.

Printed in U.S.A.

Pediat. Res. 9: 150-153 (1975)

Bilirubin deoxyribonucleic acid riboflavin hyperbilirubinemia

\title{
In Vitro Studies of Effects of Light and Riboflavin on DNA and HeLa Cells
}

\author{
WILLIAM T. SPECK, ${ }^{(23)}$ CHANG CHIU CHEN, AND HERBERT S. ROSENKRANZ \\ Departments of Pediatrics and Microbiology, College of Physicians and Surgeons, Columbia University, \\ New York, New York, USA
}

\section{Extract}

The widespread use of phototherapy for neonatal hyperbilirubinemia has caused some concern since substances other than bilirubin may be photoactivated. The toxic properties of these photoactivated substances might prove to be more harmful to the neonatal infant than bilirubin. The purpose of the present study was to investigate the effect of photoactivated riboflavin in low concentration, on purified DNA. The results demonstrate extensive changes in the structure of DNA (see Table 1) manifested by (1) a change in the peak absorbance in the ultraviolet, (2) a decrease in the temperature of the thermal helix-coil transition, (3) a slight decrease in the sedimentation coefficient, and (4) an increase in the buoyant density values $(1.704-1.709)$. These observations are consist- ent with the interpretation that there has been an alteration of one of the base moieties with minimal cleavage of the phosphodiester linkages. Results with human cells in tissue culture indicate that a similar photodynamic effect of riboflavin on the DNA occurs in living cells.

\section{Speculation}

In view of the known relation between the ability of a variety of agents to modify DNA on the one hand and the potential to induce mutation and cancer on the other, the present results suggest that riboflavin supplementation as an adjunct to phototherapy for hyperbilirubinemia requires more thorough evaluation. 
Recent discussions on the ability of riboflavin to potentiate the effect of phototherapy in neonatal hyperbiliribinemia has led to the suggestion that riboflavin be administered as a therapeutic adjunct to high intensity illumination in the jaundiced neonate $(3,7,12,16)$. This notion derives from a number of observations: (1) the finding that riboflavin enhances the rate of bilirubin photodecomposition in vitro and possibly in vivo $(3,7,12) ;(2)$ the fact that serum riboflavin in neonates undergoing phototherapy is often reduced to low levels $(16)$; (3) the observation that low doses of riboflavin increase glutathione reduciase activity $(2,16)$ and that such activity might lead to stabilization of the erythrocyte membrane and limit further hemolysis (16).

Some recent investigations to determine the photodynamic effect of riboflavin in low concentration on DNA have caused us to question the safety of riboflavin supplementation to neonates undergoing phototherapy, and to approach this question by use of in vitro models.

\section{MATERIALS AND METHODS}

\section{MATERIALS}

Calf thymus DNA was obtained from Miles Laboratories, deoxyribonucleosides from Schwarz-Mann, Inc., and riboflavin from Sigma Chemical Co.

\section{LIGHT SOURCE}

A special phototherapy unit was constructed for these experiments. The unit is protected from direct sunlight and air cooled to maintain samples at room temperature $\left(23^{\circ}\right)$. Illumination was provided by 3 special high energy blue lamps (Westinghouse F 20T 12-BB) and the sample distance from the light source was adjusted to maintain a constant irradiance of $1.7 \mathrm{~mW} / \mathrm{cm}^{2}$ between 415 and $465 \mathrm{~nm}(19)$.

\section{PHYSICAL CHEMICAL MEASUREMENTS}

Sedimentation coefficients were determined in a Spinco model $\mathrm{E}$ analytical ultracentrifuge equipped with an ultraviolet optical system (20). Solutions of DNA $(30 \mu \mathrm{g} / \mathrm{ml})$ were spun at $50,740 \mathrm{rpm}$ and pictures taken at 2-min intervals. The photographs were traced with a Joyce-Loebl Mark III B microdensitometer and sedimentation coefficients were calculated by a modification (10) of the procedure of Schachman (13).

The banding properties of DNA in gradients of cesium chloride were determined as described by Schildkraut et al. (14). Portions of the DNA together with a reference sample (Micrococcus lysodeikticus DNA, $1.731 \mathrm{~g} / \mathrm{cm}^{3}$ ) were placed in a $\mathrm{CsCl}$ solution (density $1.70 \mathrm{~g} / \mathrm{cm}^{3}$ ) and centrifuged at $44,770 \mathrm{rpm}$ for $24 \mathrm{hr}$. The bands formed by the specimens at their equilibrium positions were photogrảphed and traced as above (20).

Thermal helix-coil transition profiles were measured with a Beckman DU spectrophotometer according to the manner described by Marmur and Doty (8). The midpoint of the thermal transition $\left(\mathrm{T}_{\mathrm{m}}\right)$ was used to characterize the samples.

Spectra were determined in a Cary spectrophotometer, readings at selected wavelengths were checked with a Beckman DU spectrophotometer.

\section{TREATMENT OF SPECIMENS}

Calf thymus DNA $(1 \mathrm{mg} / \mathrm{ml} 0.015 \mathrm{M} \mathrm{NaCl}$ containing $0.0015 \mathrm{M}$ sodium citrate) solutions were supplemented with various amounts of riboflavin. A portion of each sample was kept in the dark (control) while the other was illuminated. Immediately after irradiation the samples were precipitated with 2 volumes of ethanol, washed thoroughly with ethanol, drained dissolved in $0.015 \mathrm{M} \mathrm{NaCl}$ containing $0.0015 \mathrm{M}$ sodium citrate, and processed for physical chemical analyses.

\section{EXPERIMENTS WITH CELLS IN TISSUE CULTURE}

HeLa cells were grown as monolayers $\left(4 \times 10^{6}\right.$ cells/bottle $)$ in Eagle's minimal essential medium containing glutamine and $10 \%$ calf serum. The cells were washed, supplemented with fresh medium and with $\left[{ }^{3} \mathrm{H}\right]$ thymidine $(6 \mu \mathrm{Ci} / \mathrm{ml})$, and incubation was continued for $4 \mathrm{hr}$. The monolayers were then washed and fresh medium was added. Some of the cultures received riboflavin $(25 \mu \mathrm{g} / \mathrm{ml})$ and they were incubated in the dark for $30 \mathrm{~min}$ to permit uptake of the vitamin. The cells were then washed with phosphate-buffered saline and bathed in this medium. The cells that had been exposed previously to riboflavin again received this supplement. One set of cultures was irradiated ( $1 \mathrm{hr}$ ) while their companions were kept nearby in the dark. The cells were washed with phosphate-buffered saline, removed from the surface of the plastic bottle with trypsin, harvested by centrifugation, and resuspended in 0.15 $\mathrm{M} \mathrm{NaCl}$ containing $0.015 \mathrm{M}$ sodium citrate. The cells were lysed with sodium lauryl sulfate and proteins removed by deproteinization with phenol. Portions of the ${ }^{3} \mathrm{H}$-labeled nucleic acids were layered on top of a linear alkaline sucrose gradient $(5-20 \%$ in $0.01 \mathrm{~N} \mathrm{NaOH})$ which was superimposed upon a cushion of $50 \%$ sucrose. The gradients were spun for 2 $\mathrm{hr}$ at $84,000 \times g$ and fractions were collected from the bottom. Radioactivity present in the fractions was determined by precipitation with $5 \%$ trichloroacetic acid, collection on filter discs and counting in a liquid scintillation spectrometer (11).

\section{RESULTS}

Illumination of DNA in the presence of $1.33 \times 10^{-4} \mathrm{M}$ riboflavin resulted in a decreased absorption in the ultraviolet; this was accompanied by a shift of the absorption maximum from 257.5 to $260 \mathrm{~nm}$ (Fig. 1). Such effects did not occur upon exposure of DNA to riboflavin in the dark. These spectral changes were accompanied by alterations in the physical chemical properties of the DNA. Thus the temperatures of the helix-to-coil transition was lowered. This change is a function of the vitamin concentration (Table 1). When a riboflavin concentration of $1.33 \times 10^{-4} \mathrm{M}$ was used the DNA behaved as though it had been denatured. In addition the banding properties of DNA in cesium chloride appeared to be

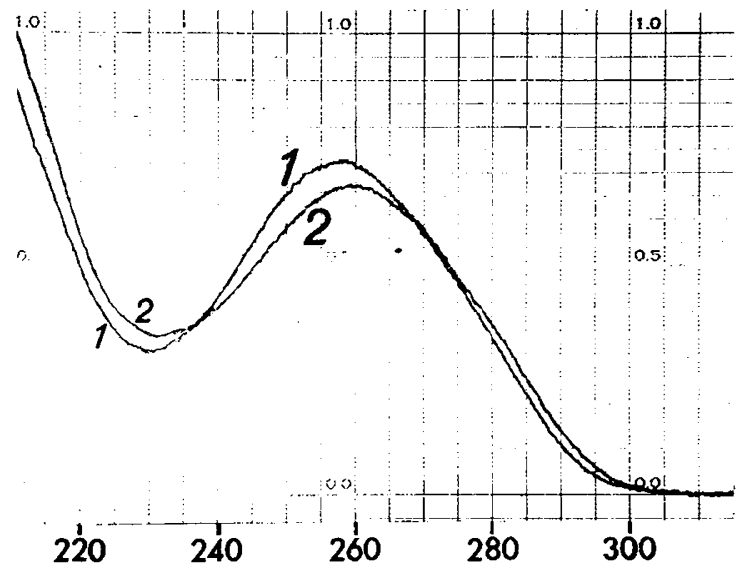

Fig. 1. Effect of irradiation in the presence of riboflavin on spectral properties of DNA. Calf thymus DNA $(1 \mathrm{mg} / \mathrm{ml} 0.015 \mathrm{M} \mathrm{NaCl}$ containing $0.0015 \mathrm{M}$ sodium citrate) was irradiated for $2 \mathrm{hr}$ in the presence or absence of riboflavin $\left(1.33 \times 10^{-4} \mathrm{M}\right)$. At the conclusion of the illumination the DNA was precipitated with ethanol, washed with ethanol, and redissolved in $\mathrm{NaCl}$ containing citrate. Portions of the stock were diluted further and their absorbance in the ultraviolet determined. DNA which was kept in the dark, irradiated in the absence of riboflavin, or supplemented with riboflavin but not irradiated exhibited normal spectra. Curves 1 and 2 represent the spectra of normal and DNA irradiated in the presence of riboflavin, respectively, 
Table 1. Effect of riboflavin on the physicochemical properties of $D N A$

\begin{tabular}{|c|c|c|c|c|c|}
\hline Expt. & $\begin{array}{c}\text { Riboflavin, } \\
\text { M }\end{array}$ & $\begin{array}{l}\text { Irrad- } \\
\text { iation }\end{array}$ & $\begin{array}{l}\text { Sedimentation } \\
\text { coefficient, } S\end{array}$ & $\begin{array}{c}\text { Buoyant } \\
\text { density } \\
\mathrm{g} / \mathrm{cm}^{3}\end{array}$ & $\mathrm{~T}_{\mathrm{m}},{ }^{\circ} \mathrm{C}$ \\
\hline \multirow[t]{4}{*}{ I } & 0 & - & 14.6 & 1.704 & 74.5 \\
\hline & 0 & + & 13.7 & 1.704 & 74.5 \\
\hline & $1.33 \times 10^{-4}$ & - & 13.6 & 1.704 & 73.0 \\
\hline & $1.33 \times 10^{-4}$ & + & 6.3 & & 35.7 \\
\hline \multirow[t]{5}{*}{ II } & 0 & + & 17.2 & 1.705 & 74.8 \\
\hline & $1.33 \times 10^{-7}$ & + & 13.9 & 1.704 & 76.1 \\
\hline & $1.33 \times 10^{-6}$ & + & 13.8 & 1.704 & 72.8 \\
\hline & $1.33 \times 10^{-5}$ & + & 13.3 & 1.709 & 65.4 \\
\hline & $1.33 \times 10^{-4}$ & + & 8.1 & 1.711 & \\
\hline III & Heated DNA & - & 16.8 & 1.722 & Denatured \\
\hline
\end{tabular}

unaffected until a riboflavin concentration in excess of $1.3 \times$ $10^{-6} \mathrm{M}$ was reached, whereupon a dramatic increase in buoyant density was observed (Table 1 and Fig. 2). Even while the thermal denaturation profiles and banding properties of the DNA were altered drastically (e.g., $1.33 \times 10^{-5} \mathrm{M}$ riboflavin), the sedimentation coefficients of illuminated DNA were not greatly affected. (For example, it can be calculated (5) that a decrease in sedimentation coefficient from 17.2 to 13.3 S (Table 1) corresponds to only a twofold decrease in molecular weight.)

Irradiation of the four usual deoxynucleosides under similar conditions revealed that only deoxyguanosine was altered (Fig. 3 , see also Reference 6).

The DNA isolated from human (HeLa) cells that were irradiated in the presence of riboflavin $(25 \mu \mathrm{g} / \mathrm{ml})$ exhibited a diminution in molecular size as evidenced by its slower rate of migration in an alkaline sucrose gradient (Fig. 4). DNA of cells irradiated in the absence of added riboflavin or exposed to riboflavin in the dark did not show this decrease in sedimentation rate.

\section{DISCUSSION}

These results indicate that illumination of DNA in the presence of riboflavin results in significant alterations of the physicochemical properties of this biopolymer. The findings are consistent with a specific photodegradation of the guanine moiety (see also reference 6). This is supported by the following.

1. Of the four usual bases in DNA, guanine is the one with the absorption maximum at the lowest wavelength $(256.5 \mathrm{~nm})$ (1), therefore, selective destruction of the guanine would shift the maximum to the higher wavelengths (this was actually observed (Fig. 1)). Moreover, it was reported earlier that apurinic acid (DNA from which guanine and adenine had been removed) also exhibited an increase in the absorption maximum (18).

2. The temperature of $T_{m}$, the midpoint of the thermal denaturation profile, is correlated with the guanine-cytosine content of the DNA (8). Hence selective destruction of guanine residues results in decreased $T_{m}$ values. It is of interest that methylene blue also causes the photodegradation of guanine residues in DNA and that this also results in a lowering of $T_{m}(15)$.

The observation that irradiation of DNA in the presence of $1.3 \times 10^{-5} \mathrm{M}$ riboflavin resulted in a significant increase in buoyant density is puzzling. It cannot be determined at the present time whether a selective degradation of the guanine residue should result in a decrease or increase in buoyant density. The buoyant density of DNA is a function of the guanine-cytosine (G-C) content (14); DNA's rich in guaninecytosine have high buoyant densities. However, when the guanine moiety is selectively altered, even when it is completely degraded, the corresponding cytosine residue is still present (albeit unpaired) and this may cause an increase in buoyant density. Further studies of the chemical nature of the riboflavin-induced photoreaction with DNA will be required to elucidate this point. At the present time it may be stated that the increase in buoyant density is not the result of extensive denaturation, as the treated DNA still exhibits thermal denaturation, although at a reduced temperature $\left(65.4^{\circ}\right)$. Untreated DNA, on the other hand, exhibits an increase in buoyant density of $0.017 \mathrm{~g} / \mathrm{cm}^{3}$ upon denaturation (Table 1 and Reference 4).

The extensive changes in spectra, thermal helix-coil transitions, and buoyant densities are not accompanied by

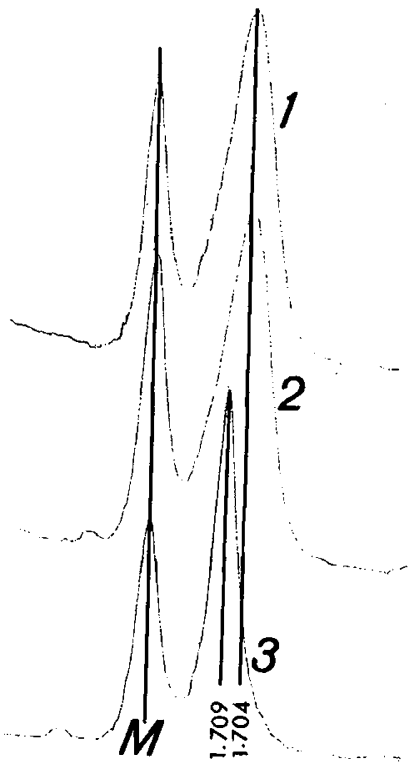

Fig. 2. Banding in gradients of $\mathrm{CsCl}$ of DNA irradiated in the presence of riboflavin. 1: control, 2, 3: DNA irradiated in the presence of $1.33 \times 10^{-6}$ and $1.33 \times 10^{-5} \mathrm{M}$ riboflavin, respectively. The band at the extreme left $(M)$, represents the position of the marker DNA (Micrococcus lysodeikticus, $1.731 \mathrm{~g} / \mathrm{cm}^{3}$ ).

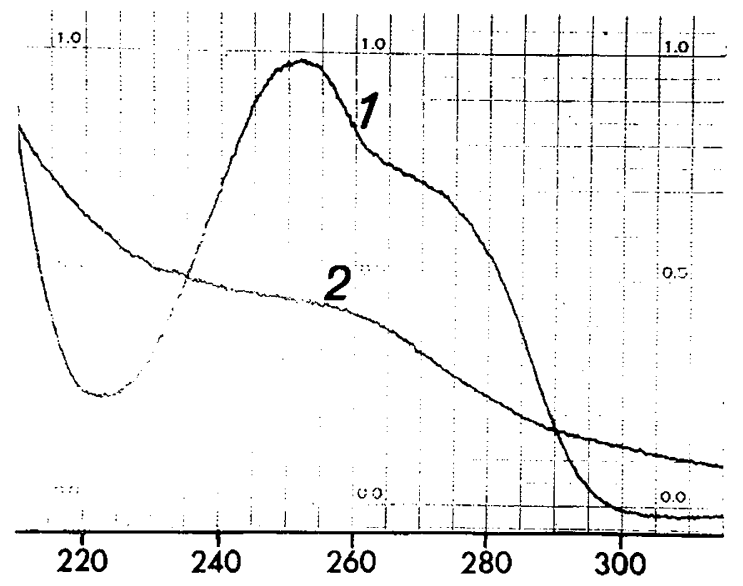

Fig. 3. Effect of illumination in the presence of riboflavin on the spectrum of deoxyguanosine. Deoxyguanosine $(1 \mathrm{mg} / \mathrm{ml})$ was irradiated in the presence of riboflavin $\left(1.33 \times 10^{-4} \mathrm{M}\right)$ for $3 \mathrm{hr}$. Portions of the specimens were dissolved in $0.05 \mathrm{M}$ phosphate buffer ( $\mathrm{pH} \mathrm{7.0)}$ and their absorbances in the ultraviolet determined. Controls of deoxyguanosine irradiated in the absence of riboflavin, or exposed to the vitamin in the dark exhibited spectral properties identical with those of untreated deoxyguanosine. 1: control; 2: deoxyguanosine illuminated in the presence of riboflavin. 


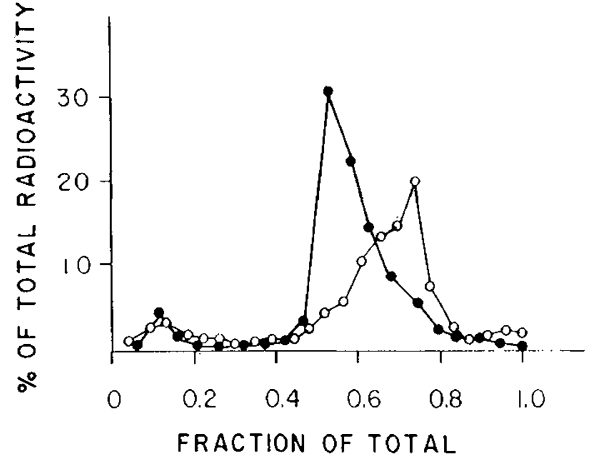

Fig. 4. Effect of riboflavin on the DNA of human cells growing in tissue culture. The DNA of HeLa cells growing in tissue culture was labeled with $\left[{ }^{3} \mathrm{H}\right]$ thymidine, whereupon a portion of the culture was supplemented with riboflavin $(25 \mu \mathrm{g} / \mathrm{ml})$ and illuminated. DNA from treated and untreated cultures was isolated and analyzed on alkaline sucrose $(5-20 \%)$ gradients. $\bullet$ : control (illuminated in the absence of riboflavin); $\circ$ : irradiated in the presence of riboflavin.

corresponding large changes in sedimentation coefficients (i.e., molecular weights). The DNA specimen that showed the increase in buoyant density with retention of the doublestranded structure still had a narrow band in $\mathrm{CsCl}$ (Fig. 2), which indicated a high molecular weight (9); its sedimentation coefficient (Table 1) can be interpretated (5) as indicating, at most, only a halving of the molecular weight. These findings suggest that scission of the phosphodiester bonds which maintain the integrity of the double-stranded DNA structure does not accompany the drastic chemical and structural changes in DNA. If the same riboflavin-induced events were to occur in vivo as well, then it can be predicted that riboflavin should be a very efficient mutagen as it would be devoid of the largely inactivating effects which are associated with cleavage of phosphodiester linkages and which reduce the efficiency of mutagenic (and possibly carcinogenic) events.

The results with HeLa cells suggest that the photochemical reaction described above also occurs in living human cells as evidenced by the lowered molecular weight of the DNA derived from cells irradiated in the presence of riboflavin. In view of the fact (see Discussion above) that cleavage of phosphodiester bonds (with a resulting decrease in molecular weight) is not a good index of the extent of the photochemically-induced alterations of the DNA, it is probable that the extent of the structural changes that have taken place in the irradiated HeLa cells are even greater than indicated by the sucrose gradients. This is being investigated further.

Under the conditions of illuminations used in this study (only a fraction of the total dose used in clinical practice), riboflavin is an excellent photosensitizer of DNA. This is due to the fact that the maximum emission of many of the light source used in phototherapy is $450 \mathrm{~nm}$ which corresponds to the in vitro absorption maximum of riboflavin. However, because this is also the in vitro absorption maximum of bilirubin, the problem created by the present observations cannot be overcome by switching to other light sources as this may lower significantly the efficiency of bilirubin photodecomposition (17).

In view of the probability that the reaction described herein also occurs in vivo and because of the known relation between ability to induce genetic and oncogenic effects, it is suggested that further studies be undertaken before riboflavin administration is used as an adjunct to phototherapy.

\section{SUMMARY}

Irradiation of purified DNA with blue light in the presence of physiologic levels of riboflavin resulted in alterations of the physicochemical properties of this biopolymer. The changes are consistent with a primary photochemical effect on the guanine moiety of DNA. Results are also presented which suggest that these changes also occur in the DNA of living cells exposed to light in the presence of low levels of riboflavin.

\section{REFERENCES AND NOTES}

1. Beaven, G. H., Holiday, E. R., and Johnson, E. A.: Optical properties of nucleic acids and their components. In: E. Chargaff and J. N. Davidson: The Nucleic Acids, Vol. 1, p. 493 (Academic Press, New York, 1955).

2. Beutler, E.: The effect of flavin compounds on glutathione reductase activity: in vivo and in vitro studies. J. Clin. Invest. 48 : 1957 (1969).

3. Broughton, P. M. G.: The effectiveness and safety of phototherapy. In: D. Bergsma, D. Y. Y. Hsia, and C. Jackson: Bilirubin Metabolism in the Newborn, Vol. 6, No. 2, p. 71. Birth Defects: Original Articles Series, 1970.

4. Doty, P., Marmur, J., Eigner, J., and Schildkraut, C.: Strand separation and the specific recombination in deoxyribonucleic acids: Physical chemical studies. Proc. Nat. Acad. Sci. U.S.A. 46: 461 (1960).

5. Eigner, J.: Molecular weight and conformation of DNA. Methods Enzymol. 12B: 386 (1968)

6. Knowles, A.: The dye-sensitized degradation of nucleotides. In: U. Gallo and L. Santamaria: Research Progress in Organic, Biological and Medicinal Chemistry, Vol. III, Part I, p. 183 (American Elsevier Publishing Co., Inc., New York, 1972).

7. Kostenbauder, H. B., and Sanvordeker, D. R.: Riboflavin enhancement of bilirubin photocatabolism in vivo. Experientia, 29: 282 (1973).

8. Marmur, J., and Doty, P.: Determination of the base composition of deoxyribonucleic acid from its thermal denaturation temperature. J. Mol. Biol. 5: 109 (1962).

9. Meselson, M., Stahl, F. W., and Vinograd, J.: Equilibrium sedimentation of macromolecules in density gradients. Proc. Nat. Acad. Sci. U.S.A., 43: 581 (1957).

10. Rosenkranz, H. S.: Ph.D. dissertation, Cornell University Graduate School of Medical Sciences, 1959.

11. Rosenkranz, H. S., Pollak, R. D., and Schmidt, R. M.: Biologic effects of isohydroxyurea. Cancer Res., 29: 209 (1969).

12. Sanvordeker, D. R., and Kostenbauder, H. B.: Mechanism for riboflavin enchancement of bilirubin photodecomposition in vitro. J. Pharmaceut. Sci., 63: 404 (1974).

13. Schachman, H. K.: Ultracentrifugation, diffusion and viscometry. Methods Enzymol. 4: 32 (1957).

14. Schildkraut, C. L., Marmur, J., and Doty, P.: Determination of the base composition of deoxyribonucleic acid from its buoyant density in CsCl. J. Mol. Biol. 4: 430 (1962).

15. Simon, M. I., and Van Vunakis, H.: The photodynamic reaction of methylene blue with deoxyribonucleic acid. J. Mol. Biol., 4: 488 (1962).

16. Sisson, T. R. C.: First International Symposium on Bilirubin Metabolism in the Newborn. Birth Defects: Original Article Series, in press.

17. Sisson, T. R. C., Kindall, N., Davies, R. E., and Berger, D.: In: D. Bergsma, D. Y. Y. Hsia, and C. Jackson: Bilirubin Metabolism in the Newborn, Vol. 6, No. 2, p. 100. Birth Defects: Original Articles Series, 1970.

18. Tamm, C., Hodes, M. E., and Chargaff, E.: The formation of Apurinic acid from the deoxyribonucleic acid of calf thymus. J. Biol. Chem., 195: 49 (1952).

19. The irradiance meter and technical assistance were provided by Dr. T. Vogl, Adjunct Professor of Radiation Physics, Babies Hospital, Department of Pediatrics, to whom we are greatly indebted.

20. We are greatly indebted to Mr. Samuel Rosenkranz without whose advice and help the ultracentrifugal analyses could not have been performed.

21. This research was supported by the George A. Carden, Jr. Special Fund for Cancer Research and by the Division of Cancer Cause and Prevention, National Cancer Institute (Contract No. NO1 CP-33395)

22. Herbert S. Rosenkranz is a Research Career Development Awardee of the National Institute of General Medical Sciences, United States Public Health Service (5 K3-GM29, 024).

23. William $T$. Speck is the Rustin-McIntosh Fellow in Pediatrics. Requests for reprints should be addressed to: William T. Speck, M.D., Department of Pediatrics, College of Physicians and Surgeons, Columbia University, 630 W. 168th St, New York, N. Y. 10032 (USA).

24. Accepted for publication August 26, 1974 